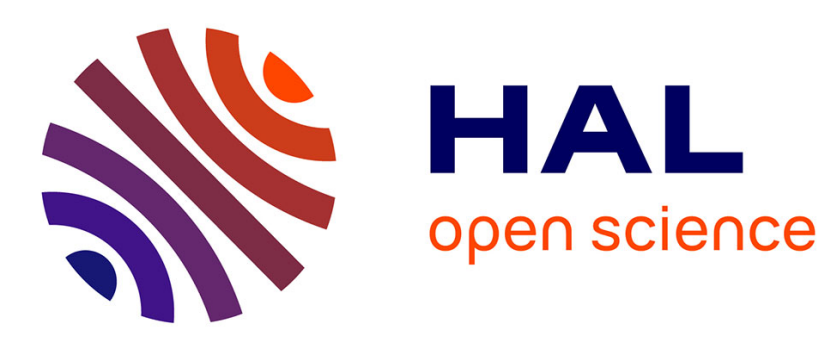

\title{
Talking about, for, and to the People: Populism and Representation in Parliamentary Debates on Europe
}

Naomi Truan

\section{To cite this version:}

Naomi Truan. Talking about, for, and to the People: Populism and Representation in Parliamentary Debates on Europe. Zeitschrift für Anglistik und Amerikanistik. A Quarterly of Language, Literature and Culture, 2019, 67 (3), pp.307-337. 10.1515/zaa-2019-0025 . halshs-02376375

\section{HAL Id: halshs-02376375 \\ https://shs.hal.science/halshs-02376375}

Submitted on 22 Nov 2019

HAL is a multi-disciplinary open access archive for the deposit and dissemination of scientific research documents, whether they are published or not. The documents may come from teaching and research institutions in France or abroad, or from public or private research centers.
L'archive ouverte pluridisciplinaire HAL, est destinée au dépôt et à la diffusion de documents scientifiques de niveau recherche, publiés ou non, émanant des établissements d'enseignement et de recherche français ou étrangers, des laboratoires publics ou privés. 
Naomi Truan*

\title{
Talking about, for, and to the People: Populism and Representation in Parliamentary Debates on Europe
}

https://doi.org/10.1515/zaa-2019-0025

\begin{abstract}
This paper contributes to the discussion on the reference to 'the people' in contemporary politics. Illuminating the tension raised by representation, this corpus-assisted analysis investigates how Members of Parliament discursively construct the necessity to represent and involve the people while being at the same time the ones holding the floor. Close analysis of British, German, and French parliamentary debates on Europe reveals that parliamentary talk relies on a twofold dynamic: enacting the people's voice and making parliamentary debates accessible. These patterns are represented in the speeches of all parliamentary groups. This shows that none of these discourse strategies are, per se, a prerogative of populist movements, thus shedding light on the necessity to think the articulation between populist style and populist ideology.
\end{abstract}

Keywords: parliamentary discourse; people; person reference; referendum; topos; Europe; populism; style; citizens; representation; corpus linguistics.

\section{Parliament, People and Representation: Populism in the Spotlight}

\begin{abstract}
"Senator, the American people, whom you often mention in your speeches, would like a word with you." This caption from a cartoon by J.B. Handelsman published in The New Yorker on 19 October 1998 perfectly illustrates the tension posed by representation in modern democracies. The image shows a senator sitting behind their desk, cut off from the long queue of people standing behind a wall. Both entities remain invisible to the other. As the people are about to crowd onto the senator's office, their secretary gives them a hint: "Senator, the American people, whom you often mention in your speeches, would like a word with you." This cartoon sheds light in a humoristic way on the perceived gap between the overrepresentation of the people in political speeches and the difficulty to get
\end{abstract}

*Corresponding author: Naomi Truan, Universität Leipzig, Leipzig, Germany, e-mail: naomi.truan@uni-leipzig.de 
access to politicians. As corpus-assisted techniques on a corpus of parliamentary debates will show, the first assumption (people are often alluded to) will prove to be correct. Why, then, do Members of Parliament seem (so) disconnected from the citizens?

\subsection{The Tension between Representation and Direct Democracy}

Members of Parliament function as representatives who are both "standing for" and "acting for" others (Pitkin 1967). This representative function, which is at the heart of modern democracies (Hermet 2001, 46), is what drives populist movements: mediation is judged as useless, unnecessary, limiting, or harmful (Taguieff 2002, 84). The question of whether populism is "a strategy, which would mean rhetoric without content, or [...] an ideology, which would allow comparisons with fascism or right-extremism" (Hubé and Truan 2016, 182), remains a heated debate. Moving past this binary opposition, it has been suggested that contemporary populism can be best understood as a communicative strategy (Higgins 2013), a political style mobilizing "repertoires of embodied, symbolically mediated performance” (Moffitt 2016, 28-29), or a discursive performance (Ekström et al. 2018).

This contribution does not ask which parties or speakers are populist, inhabit a populist style, or under what conditions they are/become populist. Rather, it explores how the call to the people, which builds the core of populist styles or ideologies for many authors, is discursively enacted. By examining the discourse strategies used to represent the people in parliamentary discourse as well as the topics addressed in such a setting, this paper connects the 'how' (the rhetoric) and the 'what' (the ideology). One of the major claims made in this paper is that giving the power back to the people is a basic component of parliamentary discourse. From this perspective, I will refrain from using the term populism to characterize the discursive phenomenon at stake. This is not so much in order to avoid taking position in the ongoing debate than because, in my view, the 'populist tag' raises more questions than answers.

Since the very raison d'être of plenary debates in the parliament - even more than any other kind of political speech - is to display positions in the political arena for the citizens, it seems logical that parliamentary discourse is, at least partly, oriented towards the people outside the parliament. Looking at the entire spectrum enables me to look into all parliamentary groups with no prior assumption regarding their populist stance. This contribution indeed examines only elected politicians, who are represented in the parliament. I argue that Members of Parliament perform three communicative acts simultaneously: they speak 
about, for, and to the people. This illustrates the dilemma Members of Parliament are faced with when, while talking to the people, they also have to talk on their behalf, but not with them. The main contributions of this article can be summed up as follows: first, talking about the people or even on their behalf is not, as such, an indicator of populism: every politician in the corpus does it. Second, when they talk about the people, Members of Parliament do not include themselves: their task is to represent and teach the people, but they do not see themselves as belonging to the people.

How, then, do Members of Parliament account for the necessity to mention the people without highlighting their position of representatives? As I have observed elsewhere, "MPs may enunciate their proximity to the citizens, but they face a paradoxical situation, since they precisely belong to the representative system that prevents people from voicing their opinions directly." (Truan 2019a, 204). The question has recently received attention in linguistics from two different perspectives, depending on whether it proceeds from the concept of populism (which would correspond to an onomasiological approach) or the lexeme people (which would be consistent with a semasiological approach).

\subsection{Populism, the People - the Chicken or the Egg?}

A first stream of research explores the idea of a populist style. In a French context reluctant to use the term populism, the former president Sarkozy is one of the few political actors described as populist (see Hubé and Truan 2016, 183). Drawing on a corpus-driven methodology, Mayaffre and Scholz show that Sarkozy's political style can be understood as populist because it combines a series of features: positioning as "the spokesperson of the people" (2017, 685), "construction of an enemy which often serves as a scapegoat for the problems enacted skillfully" (2017, 688), frequent use of demonstrative pronouns $(2017,697)$, in particular 'this' (ça) and 'one' (on) creating “a vague threat” (2017, 700). Rabatel (2016, para. 4) interprets the use of "enunciative erasing, generic and generalizing utterances" as an "essentializing strategy" typical for Nicolas Sarkozy. Yet the qualitative analysis does not build on comparative data (from other speakers or other parties), thus making it difficult to assess whether the analysis applies for Sarkozy only or specifically.

In David Cameron's speeches, the construction of "the productive citizen" (Higgins 2013, 63) leading to a "rhetoric of empowerment" $(2013,68)$, together with "the flexibility of the address" $(2013,67)$ and "strategies of particularisation" (2013, 65), contribute to the populism of the former Prime Minister. Similarly, in Germany, PEGIDA and the AfD have been analyzed as populist movements 
(Vorländer et al. 2018). In her book on right-wing populist discourse, Wodak (2015) argues that right-wing populism builds on norms and taboos violations, nationalism, scapegoats (antisemitism), a charismatic leader, promoting patriarchy, and normalizing exclusion. Taking populism as a vantage point, these studies elicit features of the populist style, sometimes tied up with a right-wing ideology.

Another way to address this issue is to ask how 'the people' - whoever they may be - are represented in political discourse. While numerous studies examine collective nouns in general (see Lecolle 2013; Cappeau \& Schnedecker 2014; Boughanmi 2016; Schnedecker \& Mihatsch 2018 for French from a lexical/ semantic perspective; Hoffmann 1991; Retterath 2016 for German from a historical perspective), there is no focus on political discourse specifically. The question of what discourse strategies are used to instantiate 'the people' thus warrants further investigation. From this vantage point, I examine whether referring to the people, both in terms of frequency and nature, can be assessed as populist. As I will show, person-referring expressions with generic reference are a common feature of political discourse and cannot be linked with any specific speaker or any specific parliamentary group.

\subsection{A Contrastive Corpus of Parliamentary Debates}

This paper takes the dilemma of representation seriously by exploring how the people are represented in British, German, and French parliamentary debates on Europe between 1998 and 2015 - when the UK was still an EU Member State. I argue that the contrastive approach not only sheds light on the similarities and discrepancies of parliamentary debates in France, Germany, and the United Kingdom, but crucially enables a better understanding of how Members of Parliament represent the people in three different settings (see Truan 2019b).

The corpus-assisted analysis relies on 44 plenary sessions retrieved from the respective websites of the parliaments and annotated in a TEI XML format. The three corpora are available online in open access (Truan 2016a,b,c). The decisions underlying the text selection and the corpus annotation are anchored in the necessity to make the corpora comparable; thus one parliamentary debate per year about a major European Council meeting (ex ante, ex post, or on the same day) was selected. In each country, parliaments are divided into working groups that gather expertise on a specific topic. Being thematically linked with one another, the parliamentary sessions display a core group of speakers: the same Members of Parliament are participating in the discussions over the years.

The parliamentary debates considered were held in preparation or reaction to scheduled European Councils, informally referred to as EU summits, i.e. neither 
informal nor extraordinary meetings. The European Council is an institution of the European Union comprising heads of state or government of EU Member States, which "functions as the principal agenda-setter, the ultimate arbiter in decision-making, and the motor behind European integration" (van de Steeg 2010, 118). Recent research has shown that European Council meetings trigger plenary debates in the EU Member States, nonetheless in very different proportions. These discrepancies are reflected in the size of the corpora: the German corpus is the biggest one with 417,095 tokens, while the British and the French one amount for 188,913 and 137,620 tokens, respectively.

The analysis combines a corpus-assisted approach with a discourse-analytic perspective. The paper begins with a lexeme-based account, and then proceeds to an argumentative and rhetoric study. Section 2 delves into the representation of the people by focusing on lexemes encoding human referents: 'people,' 'citizen(s),' 'constituent(s),' 'voter(s).' It unravels the similarities and differences between these terms in English, German, and French, and accounts for both semantic features and institutional mechanisms. Drawing on rhetorical and argumentative features, Section 3 is devoted to the topos of 'Europe as a Machinery.' This topos encompasses two discursive moves: making Europe understandable for everyone and educating the people by explaining Europe. I conclude by highlighting the unresolved tension between the necessity to speak on behalf of the people and appeals for more direct participation.

\section{Representing the People: Enacting the People's Voice(s)}

In this section, I present results based on lexemes encoding human referents. Representing the people entails two questions: how and why do Members of Parliament mention their constituents? To answer the first question, I have looked for all the forms related to a limited amount of nouns denoting human agents: singular/plural, feminine/masculine, in all the cases (for German). When referring to the lemmas, "the canonical form of a word" (Baker et al. 2006, 104), i.e. a "set of lexical forms having the same stem and belonging to the same major word class, differing only in inflection and/or spelling” (Francis and Kučera 1982, 1), I indicate the word as it appears in the software $\mathrm{TXM}^{1}$ used to perform the queries: in the singular masculine form.

1 The software TXM is an "open-source textual analysis software compatible with the TEI encoding scheme" (Heiden 2010, title of the paper). The software is freely downloadable at: http:// textometrie.ens-lyon.fr/?lang=en (accessed on 09.07.2019). 
I first delve into the representation of 'the people' and study some collocation patterns. The corpus shows that the people are used to introduce public concerns and values and are invoked for the speaker's argument. Claiming that one knows what people want, feel, or fear is indeed a fruitful resource in political discourse. I then explore the variety of person-referring expressions involved, and account for similarities and differences between the various nouns involved to denote 'the people.' I argue that a semantic explanation accounts for the various uses of these lexemes in English, German, and French. I finally look at nouns whose scope of reference is more restrictive. I turn to nouns expressing the possession of civil rights (notably the right to vote) such as voter(s), citizen(s), Bürger*in(nen), (con) citoyen ·ne(s), constituent(s), Wähler*in(nen), électeur/-trice(s), compatriote(s). ${ }^{2}$ These apparent equivalents activate different representations. I argue that when semantics fall short, the differences can also be explained by diverging institutional norms, in particular regarding the electoral system and the collective image of parliamentary representation in each country.

\section{1 'That is What People Want': ${ }^{3}$ Mapping out Expectations}

This section is devoted to one of the most productive contexts of apparition of the noun 'people' and related lexemes: in utterances where the feelings and thoughts of the people are orchestrated. In such cases, nouns denoting human referents combine four properties that I will briefly present before discussing in more detail the last two.

First, the people are referred to as a group, presupposed as a monolithic entity, which is linguistically encoded in the predominant use of the plural. There are for instance 427 occurrences of the German noun Menschen in the plural ('people'), but only 8 in the singular. The 'citizens' (Bürger) are primarily mentioned in the plural (250 occurrences), with some few exceptions in the singular (11 occurrences in the singular masculine form). 'The Germans' (Deutsche) are also invoked in the plural in the majority of the cases (62 occurrences out of 65). In French, the picture is even more contrasted: all the occurrences of 'the French' (Français) are in the plural. Similarly, there are 33 occurrences of the noun constituents in the plural in the British corpus, but only 3 in the singular. For all other lexemes (apart from collective nouns, which are morphologically singular, and pluralia tanti, which are conversely plural), the number of occurrences remains too small to be representative (see Table 1). When used in the plural, the noun phrases either correspond

2 The lexemes are indicated with quotations marks when I am referring to their discursive representation in the three languages (or to the English translation). I use italics to refer to the lexemes in English, French, and German, respectively.

3 Quote from the corpus by Mr. David Cameron (Tories) [majority], UK 2014.10.27. 
Table 1: Selected lemmas denoting human referents in the British, German, and French parliamentary corpora (per raw frequencies and per 10,000 tokens).

\begin{tabular}{lrlrlr}
\hline UK-PARL & & DE-PARL & \multicolumn{2}{l}{ FR-PARL } & \\
\hline people & 441 & Volk & 73 & peuple & 170 \\
& 23.3 & & 1.7 & & 12.3 \\
& & Mensch & 435 & & \\
& & & 10.4 & & \\
& & Leute & 55 & personnes/gens & 12 \\
& & & 1.3 & & 0.9 \\
\hline public & 19 & & & & \\
& 1 & & & & $114+40+10$ \\
citizen & 1 & Bürger & 261 & citoyen/concitoyen/compatriote & 11.9 \\
& 1.5 & & 6.2 & & 7 \\
\hline constituent/voter & $36+12$ & Wähler & 15 & électeur & 0.5 \\
& 2.5 & & 0.35 & & 38 \\
\hline British (people) & & Deutsche & 65 & Français & 2.8 \\
& & & 1.6 & &
\end{tabular}

to a fair amount of discourse participants ('most people,' 'many people') or, more frequently, activate a generic reading (bare plurals in English and German, definite plurals in German and French).

Second, people are overwhelmingly described as agents, a phenomenon that correlates with their frequent syntactic position as subjects in a sentence. Deriving from the observation, the third property consists in the association of human referents with cognitive verbs such as 'think': the people are given the power to collectively worry or want things. Fourth, no or very few hedges are introduced when referring to people.

Let us begin with the third property, i.e. the association of people with cognitive verbs or feelings:

(1) Mr. William Hague (Tories) ${ }^{4}$ [opposition]: Does the Prime Minister not recognise that most people in this country do not want any more powers transferred from Britain to European institutions? They want their taxes decided in this House, and oppose his plans to scrap the pound. They want to be in Europe, not run by Europe. (UK 1999.06.08) ${ }^{5}$

4 I refer to the British Conservatives as the 'Tories' because the label 'Conservative' has been used for the common political affiliation of all Conservative parliamentary groups in the three corpora with the TEI tag <affiliation>.

5 The indication in brackets corresponds to the ISO country code, followed by the temporal indication year.month.date as for the day on which the parliamentary debate took place. 
(2) Mr. David Cameron (Tories) [majority]: Those are things that I suspect each and every one of the hon. Gentleman's constituents wants put in place. (UK 2015.03.23)

In examples (1) and (2), Members of Parliament claim that they know what people want. In the British corpus, the lemma want co-occurs 33 times with the lemma people (440 occurrences) and six times with the lemma constituent (36 occurrences). Although these figures remain relatively small, they point towards a pattern. This is not the case for the French verb vouloir ('want') or the German verb wollen ('want'), however. This can be explained by the multiplicity of expressions denoting humans in French and German, whereas in the British corpus, three main lexical items concentrate the reference to the people: people, public, constituent (see Table 1).

Apart from collocations that are thematically expected given the common topic on Europe ('Europe,' 'European'), two main collocation patterns are visible. First, the lexical field of expectations frequently co-occurs with two of the French nouns under investigation: répondre, attente, inquiétude, préoccupation ('answer,' 'expectation,' 'worry,' 'concern') are among the first lemmas co-occurring with the lemma concitoyen ('fellow citizen') (second, third, sixth, and seventh position, respectively). ${ }^{6}$ The pattern is less marked with the lemma citoyen ('citizen'), in particular because one of the parliamentary groups is named 'Groupe socialiste, radical, citoyen et divers gauche.' When only citoyens ${ }^{7}$ in the plural is considered, the link with Europe is manifest: the lemmas Europe and européen appear in the first and second position, respectively, followed by collocations linked with expectations as well: sentiment, attendre, attente ('feeling,' 'expect,' 'expectation'). While this pattern is less present in the German corpus, it appears as well: the noun phrase die Sorgen der (Bürgerinnen und) Bürger ('the citizens' worries') occurs five times, and the verb empfinden ('feel') co-occurs with the lemma Bürger on three occasions.

This pattern reflects the necessity, for Members of Parliament, to speak on behalf of the people, and by doing so, to formulate what the people supposedly - want. It may be hypothesized that this pattern is not typical for parliamentary debates on Europe, however, and that this is a more general feature of parliamentary discourse.

6 Other collocations are linked with the topos of Europe hard to grasp for the public described in Section 3.

7 The lexeme citoyennes (1 occurrence) is used as an adjective: manifestations citoyennes ('civic protests') (FR 2002.12.03). 
The second pattern is specific for parliamentary debates on European affairs. The second cluster of collocations pertains to the need for transparency, democracy, and explanations. It is also visible in the following collocations of the French noun citoyen ('citizen'), which highlight the necessity to reconstruct Europe by strengthening the link to the citizens: protéger, construction, démocratique, fossé, leur, redonner ('protect,' 'construction,' 'democratic,' 'gap,' 'their,' 'give back'). In English, the collocations for the collective noun public (distinct from the adjective) also yield similar results: apart from British (first collocation), understand and persuade are ranked second and third. As discussed in Section 3, the link between the will to influence (persuade) and explaining (understand) is already visible. In German finally, the lemma Bürger ('citizen') shows a similar collocational behavior as French citoyen regarding the connection to Europe: apart from Bürgerin and und in the first and second position given the pervasiveness of the noun phrase Bürgerinnen und Bürger ('citizens', both in the masculine and feminine forms), ${ }^{8}$ the most frequent collocations are Europa, transparent ('Europe,' 'transparent'), followed later by europäisch, verständlich ('European,' 'understandable').?

From this overview we see that the mention of the people in parliamentary debates on Europe serves two main goals: outlining people's expectations (thus the mention of people's concerns) and sketching the complexity of European issues (thus the mention of what people (do not) understand, as will be further explored in Section 3).

Let us now turn to the fourth property: what the people think or feel is implicitly described as what all people think or feel. This is visible through the use of noun phrases with generic reference. Although the scope of reference of nouns referring to people may be partially restricted by quantifiers ('most,' 'many,' or 'some,' especially when referring to opponents rather than 'the people'), the claims made on behalf of the people are usually uttered in a straightforward manner:

8 "In German political discourse specifically, it has become usual - or politically correct - to use both forms: among 261 occurrences of Bürger as a lemma in the corpus, 152 are feminine. This means that in $58 \%$ of the cases, the noun phrase becomes die Bürgerinnen und Bürger, almost systematically in this word order (plural feminine form followed by the plural masculine form)" (Truan 2019a, 206).

9 The other collocates are Bürger in fourth position (between Europa and transparent), the definite article die in sixth position (as in die Bürgerinnen und Bürger), Million in seventh position, and für in eighth position. The fact that the lemma Bürger may be subject to quantification ('millions') shows that it clearly differs from the collocational analysis of constituent (see Section 2.3). The preposition für ('for') indicates that 'citizens' are exposed to government's policies, as will be shown in Section 3. 
(3) Volker Kauder (CDU) [majority]: Diese Koalition dient dem Land in vorbildlicher Weise. Das mag der Opposition nicht passen, aber die Menschen im Land sehen es anders. Dort ist die Große Koalition zu Recht beliebt. (DE 2015.03.19) Volker Kauder (CDU) [majority]: This coalition serves the country in an exemplary way. That may not fit the Opposition, but people in this country see it differently. There the grand coalition is rightly popular.

(4) Mr. Tony Blair (Labour) [majority]: That matter is simply not on the agenda, and most people understand why - because it is right that Parliaments set national taxes in the way that they wish. (UK 1998.12.14)

(5) Jérôme Lambert (Socialiste) [opposition]: Attentifs à ce que nous entendons, nous avons donc le devoir et la responsabilité de dire au Gouvernement ce que le peuple nous demande, ce qu'il souhaite et parfois aussi ce qu'il craint. Quand j'écoute mes compatriotes me parler de l'Europe, je constate souvent qu'un fossé se creuse entre les idéaux qu'ils peuvent encore partager, un espace de paix en particulier, et les multiples aspects, souvent complexes, de la construction et de la politique européennes. Les citoyens ont, de fait, le sentiment d'être de plus en plus éloignés des décisions qui les concernent et qui sont prises au niveau européen. Ils n'en comprennent pas toujours les mécanismes, et considèrent ne pas avoir un pouvoir de contrôle et d'action sur la politique de notre pays. Les citoyens, bien souvent, nous font part d'un sentiment d'impuissance, qui se traduit aussi trop souvent par un rejet malheureusement exploité, parfois, par tous les extrémistes. (FR 2002.12.03)

Jérôme Lambert (Socialiste) [opposition]: We have to pay attention to what we hear and, therefore, have a duty and responsibility to tell the Government what the people ask us, what they want and sometimes also what they fear. When I listen to my compatriots talk to me about Europe, I often find that there is a widening gap between the ideals they can still share, an area of peace in particular, and the many, often complex, aspects of European construction and politics. Citizens actually feel increasingly distant from the decisions that affect them and that are taken at European level. They do not always understand its mechanisms, and consider that they do not have the power to control and act on the policy of our country. Quite often, citizens tell us of a feeling of helplessness, which also too often results in rejection, unfortunately exploited, sometimes by all extremists.

Despite some restrictions, notably through the use of numerical adverbial quantifiers ('(quite) often') in (5), the speakers present the views attributed to the people as representative of the majority of those people. When it comes to saying what 
people 'see,' 'understand,' and 'ask for,' there is no room for doubt or modality (also see Truan 2019a, 221).

From the analysis of these examples, we may conclude that claiming 'that is what people want' is a resourceful strategy in parliamentary discourse. As they are presented as a group in the plural, 'the people' become a powerful and unquestioned majority expressing ideas and wishes supporting the politician's argument. Instead of talking to the people, Members of Parliament thus rather talk on their behalf.

\subsection{Referring to 'the People': A Multiplicity of Expressions}

The reference to the 'people' is usually encoded in the lemmas people in English, Mensch and Bürger in German, and peuple and citoyen in French. ${ }^{10}$ Table 1 presents an overview of the nouns denoting human referents in the three parliamentary corpora, per raw frequencies and per 10,000 tokens.

With 441 occurrences in the corpus, English people is by far more common than constituent (36 occurrences, among which 33 in the plural) or citizen (28 occurrences, among which 27 in the plural). The collective noun public occurs only 19 times. This order reflects a more general pattern: in the British National Corpus (BNC), people is also a relatively frequent term that amounts to 9 occurrences for 10,000 tokens (Truan 2019a, 208). In German, a similar distribution can be observed: the lemma Mensch (435 occurrences, among which 427 in the plural) prevails over Leute (55 occurrences) and Wähler ('voter') (15 occurrences, among which 13 in the plural). The noun Bürger ('citizen') appears more widely used than its British counterpart, and often competes with Mensch: both forms are used in similar contexts. ${ }^{11}$ The nationality noun Deutsche ('the Germans') also occurs far less frequently (65 occurrences). Given Germany's past, the collective noun Volk ('the people') (73 occurrences, among which 47 in the singular) is only used cautiously and prone to metalinguistic digressions - a topic that would nevertheless exceed the scope of this paper (see Retterath 2016; Truan 2019a, 209213). In French finally, the lexemes (con)citoyen and peuple outreach all other nouns, with 154 and 170 occurrences, respectively, while personnes and gens, two

10 This claim does not aim to reduce the complexity of the instantiations of human referents in British political discourse to the lexeme people, however, and I am aware of other (rare) occurrences such as the whole country will ask (UK 2007.12.17). Given the difficulty to establish a list of nouns denoting human referents, Table 1 presents only a selection (for a general approach, see Schnedecker and Mihatsch 2018).

11 Two exceptions can be noted: semi-fixed NPs such as 'people with disabilities' (Menschen mit Behinderung, 2 occurrences) and 'young people' (junge Menschen, 6 occurrences). 
pluralia tanti for 'the people,' amount together for 12 occurrences of the corpus. The situation of French peuple is nevertheless different from English people since it roughly translates as 'a people,' not 'the people,' and is typically used in the plural (104 occurrences out of 170, i.e. approximately $61 \%) .^{12}$

As became apparent from this overview, French and German exhibit a variety of linguistic forms where the English people encompasses almost all uses. The English lexeme people is semantically less precise and shows a relative openness. This can be explained by the semantics of English people, which has a wider scope of reference and shows a certain plasticity, defined as the ability to denote both in-group members (usually referred to as 'most people') and out-group members whose arguments the speaker rejects ('some people'). As I have shown elsewhere (Truan 2019a, 223), German Mensch does not show this plasticity and is only used to refer to in-group members. In order to refer to a multiplicity of voices - which is not necessarily rendered with the collective noun peuple -, French parliamentarians accordingly use various linguistic expressions: citoyens, concitoyens, compatriotes.

These findings lead us to rethink the link between the mention of the people and populism. First, it is important to acknowledge the absence of equivalents between English people and possible translations such a Volk, Menschen, and Leute in German and peuple, personnes, gens in French, respectively. Moreover, while one could be tempted to associate populism with the mention of the people, referring to 'the people,' and, by doing so, to what 'the people' want, is a basic component of parliamentary discourse. ${ }^{13}$ Previous research has shown that the practice of speaking on behalf of the people could be interpreted as one of the features of a populist rhetoric:

Cameron has moved beyond speaking on behalf of people to an act of ventriloquism on their behalf, where he performs a series of demands towards himself. This is the rhetorical technique of ethopoeia - common in populist discourse - which involves speaking on behalf of another, in a way that claims understanding of their motives and feelings (Higgins 2013, 64)

12 In French, the mention of peuples in the plural remains limited to a discursive event: the discussions around the 2005 referendum on the Treaty establishing a Constitution for Europe (Truan 2019a, 213-216).

13 This is why the NP the people, in English, yields 63 occurrences, while there is no reference to $a$ people in the corpus. Among those 63 occurrences, 24 refer to specific groups of people with limited to no connection with the UK (in decreasing frequency: the people of Europe/the (European) Union, 7 occurrences; the people in/of Kosovo, 5 occurrences; the people of Afghanistan, 3 occurrences; the people of (a democratic) Serbia, 3 occurrences; the people of Zimbabwe, 2 occurrences; the people and Government of Montenegro, the people of Burma, the people of the Federal Republic of Yugoslavia, the people of Tunisia, 1 occurrence each). 
The corpus-assisted investigation of British, French, and German parliamentary corpora shows in fact that the lexical field of expectations and wishes frequently co-occurs with person-referring expressions. Whether this pattern is more frequent in populist discourse still needs to be explored. What is visible in the corpus, however, is that all Members of Parliament position themselves as those who know what people want. In doing so, they highlight both their closeness to the people (repeating what they assumingly heard from the people) and their distance from them (the people's voice cannot be directly heard, it has to be reproduced by the parliamentarians in an institutional setting).

\subsection{Constituent, Électeur, Wähler: All the Same Story?}

Now that I have presented the differences in terms of frequency between nouns denoting human referents in parliamentary discourse, we can ask: are there significant differences between these forms regarding their scope of reference or can they all be used interchangeably? I will first investigate the English lexemes constituent and voter, as well as their possible equivalents in French (électeur) and German (Wähler). I will show that while the noun constituent, in English, is associated with the speaker, the semantic prosody of the French and German terms is rather negative. In order to account for lexemes corresponding to constituents, it is thus necessary to consider instances of 'citizens' (citoyen, concitoyen, compatriote in French, Bürger in German).

Let us begin with the nouns referring to constituents. Interestingly, among the 36 occurrences of the lexeme constituent in English, 22 (i.e. approximately 61\%) are preceded by the singular possessive pronoun my as in the NP my constituents. A collocational analysis substantiates this finding since the possessive pronoun $m y$ is the first collocation of the lemma constituent (co-frequency of 34 for 581 occurrences of my as a lemma in the corpus) and me the second one. For other lexemes, there are no possessive pronouns among the first ten collocations. Eight occurrences refer to my hon. Friends constituents or his constituents and only two to our constituents. The rest consists in plural noun phrases (see below) or singular noun phrases (one constituent, constituent after constituent, 2 occurrences). There is thus a close relationship - in terms of possession - between the speakers and the referents they are enacting with the noun constituent. Unsurprisingly, one can conclude that the noun constituent is closely linked to the Member of Parliament speaking on their behalf, as in (6) and (7):

(6) Henry Smith (Tories) [majority]: The constituents to whom I spoke over the weekend, on the doorstep and in community meetings, were certainly 
not amused by the irony of a surcharge of 1.7 billion from the European Union having to be paid because our economy is so successful, and they were very much behind my right hon. Friend in wanting to say no to the payment. Does the Prime Minister agree that we should take no lessons from the Labour party, who gave away 7 billion in terms of our rebate in return for absolutely no reform of the European Union? (UK 2014.10.27)

(7) Jason McCartney (Tories) [majority]: My constituents do not give a Yorkshire pudding about who said what and when. What they do care about is Labourrun Kirklees council looking at not filling in potholes, consulting on whether to keep libraries open and struggling on funding. Will the Prime Minister, on behalf of my constituents, continue to pledge to say no to this huge bill, so that we can spend money right here on our constituents?

Mr. David Cameron (Tories) [majority]: My hon. Friend is absolutely right: people want us to stand up against unacceptable bills from Brussels and make sure that money is spent on our people's priorities. (UK 2014.10.27)

Examples (6) and (7) illustrate the fact that the mention of the constituents rarely co-occurs with a quantification such as the vast majority of my constituents (1 occurrence), many of my constituents (3 occurrences) or the cardinal number thousands in thousands of my constituents (1 occurrence). These five examples are indeed the only occurrences - out of 36 - providing a quantification over the class 'constituents.' The class is perceived as a whole and stands as a single discourse entity, thus triggering a process of homogenization.

The constituents or voters are mobilized to support the speaker's views. The allusion to voters helps prepare the question asked to the Prime Minister by stressing that the speaker and their party members act in line with people's expectations. Interestingly, there is no real difference between the lexemes constituent and voter apart from the fact that when referring to other countries, only the word voter is used (French voters in UK 2012.10.22, German voters in UK 2012.10.22), which is consistent with the fact that a constituency corresponds to an electoral area in the British electoral system.

The link between the British Members of Parliament and their constituents is stronger than in the French Assemblée nationale. This is visible through the mere number of occurrences: only seven occurrences of the lemma électeur appear in the corpus. There is no direct equivalent to the English term constituent in French since the noun circonscription ('constituency') has no related term for people belonging to it. Thus, French has only électeur at its disposal, which is probably closer to 'voter' (etymologically, the électeur is the one who elects, i.e. votes for). Moreover, among the seven occurrences of électeurs (in the plural in six cases out of seven), none 
is paired with a first-person possessive pronoun, neither singular (mon, mes), nor plural (notre, nos). The French 'constituents' always embrace the figure of the other:

(8) Hervé de Charette (UMP) [majority]: Mais il sera difficile d'oublier que le parti socialiste, seul dans ce cas en Europe, aura été incapable de parler d'une seule voix, brouillant ses messages et jetant le trouble parmi ses électeurs, laissant du même coup à l'UMP le privilège qu'elle ne réclamait pas : celui d'être le seul grand parti de France à mener une campagne positive, forte et claire ! (FR 2005.12.13)

Hervé de Charette (UMP) [majority]: But it will be hard to forget that the Socialist Party, alone in this case in Europe, will have been unable to speak with one voice, blurring its messages and causing confusion among its constituents, leaving at the same time the UMP the privilege it did not claim: that of being the only major party in France to lead a positive campaign, strong and clear!

(9) Pierre Lellouche (UMP) [majority]: Je vous demande de réfléchir aux points communs qui existent entre vous, communistes, l'ultralibéral Vaclav Klaus et le conservateur britannique David Cameron. Si vous trouvez la réponse, je crois que vous finirez peut-être, un jour, par retrouver vos électeurs. (FR 2009.10.14)

Pierre Lellouche (UMP) [majority]: I ask you to reflect on the commonalities that exist between you, communists, the ultra-liberal Vaclav Klaus and the British Conservative David Cameron. If you find the answer, I think you may end up finding your constituents one day.

(10) Valéry Giscard d'Estaing (UMP) [majority]: Un élément constant du débat européen français disparaîtra enfin et vos électeurs ne vous demanderont plus en vain: "Mais pourquoi l'Europe se mêle-t-elle de tel ou tel sujet?" Vous pourrez alors leur répondre que vous avez considéré qu'elle n'avait pas en effet à s'en mêler et que vous avez voté en ce sens. (FR 2002.12.03)

Valéry Giscard d'Estaing (UMP) [majority]: A constant element of the French European debate will finally disappear and your constituents will stop asking you in vain: "But why does Europe interfere with this or that subject?" You can then answer them that you considered that it did not indeed have to interfere and that you voted for it to be so.

From excerpts (8), (9), or (10), it appears that the noun électeur activates negative representations in French politics: the constituent/voter is the person that the other party has lost, as inferred from the verb 'find again' (retrouver) in (9), either 
because the out-group members could not take a clear position in (8) or cannot answer the constituents' questions (see 'in vain') in (10).

The distribution of the German lemma Wähler is not so strongly marked: on the one hand, there are associations with the speaker through the plural possessive pronoun unser ('our') in four occurrences out of fifteen (interestingly, not with the singular possessive pronoun meine, 'me'), on the other hand, voters are also mentioned when blaming political opponents for despising them, as in (11) or (12):

(11) Gunther Krichbaum (CDU) [majority]: Wir tragen die Verantwortung gegenüber unseren Wählerinnen und Wählern. (DE 2009.09.08) Gunther Krichbaum (CDU) [majority]: We are responsible to our voters.

(12) Dr. Andreas Schockenhoff (CDU) [opposition]: Lieber Kollege Fischer, die Wähler sind nicht so blöd, dass sie das nicht merken. (DE 2004.11.11) Dr. Andreas Schockenhoff (CDU) [opposition]: Dear Colleague Fischer, the voters are not so stupid that they do not notice that.

Since the lexemes électeur and Wähler only partly cover the scope of reference of English constituent, other lexemes must be taken into consideration. How are citoyen, concitoyen, compatriote in French and Bürger in German used in parliamentary discourse? Note that the lemma citizen is a hapax in the British corpus (1 occurrence) and will therefore not be analyzed. As I have shown that the French citoyens ('citizens') are referred to in similar ways as English people, I focus, in the next pages, on the less frequent instances of concitoyen/compatriote and Bürger. The French lemmas compatriote and concitoyen, contrary to électeur, are similar to English constituent. The non-correspondence between the nouns shows how intricate contrastive discourse analysis is. Although compatriote and concitoyen would be translated as 'citoyen' in English, they actually correspond, in discourse, to the uses of the English noun constituent.

Among the ten occurrences of compatriotes, all in the plural - admittedly a small number, but patterns are already visible -, all but one correlate with the first-person plural possessive pronoun nos. Similarly, the first collocate of concitoyen is the lemma notre ('our'): all the 40 occurrences of concitoyens all in the plural, too - are preceded by the possessive pronoun nos ('our'), as in (13): ${ }^{14}$

(13) Jérôme Lambert (Socialiste) [opposition]: Grave constat, mais qui peut le nier aujourd'hui quand on écoute, comme nous le faisons tous, nos concitoyens?

14 Interestingly, there are no occurrences of 'our citizens' (nos citoyens) in the corpus. 
Je crois que là est le premier enjeu de l'évolution de la construction européenne. En effet, comment aller plus loin, comment ne pas provoquer le rejet de ce qui existe déjà, si nous ne répondons pas à l’inquiétude et aux attentes de nos concitoyens à ce propos? (FR 2002.12.03)

Jérôme Lambert (Socialiste) [opposition]: [This is a] serious observation, but who can deny it today when one listens, as we all do, to our fellow citizens? I believe that this is the first issue of the evolution of the European construction. Indeed, how to go further, how not to provoke the rejection of what already exists, if we do not answer to the worry and expectations of our fellow citizens in this regard?

Example (13) illustrates the strong collocational pattern of the terms citoyens and concitoyens ('citizens' and 'fellow citizens') with the lexical field of expectations and worries (see Section 2.1). Extract (13) condenses several characteristics typical for sharing common ground: assuming that everyone agrees, or that 'nobody can deny it' as a paraphrase of the rhetorical question 'who can deny it?,' constructing the absence of dissent around a conditional structure (here expressed temporarily through 'when' in 'when one listens') and the pronoun on ('one listens'), and finally addressing the role of parliamentarians as an 'answer' to the concerns expressed by the citizens, which is a current pattern in parliamentary discourse on Europe.

In German, the NP 'our citizens' (unsere Bürgerinnen und Bürger) with the possessive pronoun unsere yields only eleven hits - out of 261 occurrences of the lemma Bürger - and the NP 'the citizens of our country' (die Bürgerinnen und Bürger unseres Landes) is slightly less frequent (5 occurrences). A combination of both, the NP 'the people of our country (and in Europe)' (die Menschen in unserem Lande (und in Europa)) is also relatively rare (7 occurrences out of 435). Some nouns trigger an association in terms of possession: my constituents in English, nos concitoyens and nos compatriotes in French. Compared to these lexemes, the German lemma Bürger ('citoyen') occupies a middle position: it is overwhelmingly used generically with the plural definite article die (die Bürgerinnen und Bürger), yet this does not exclude uses where the scope of reference of the 'citizens' is anchored in a national context through the possessive pronoun 'our' (unsere Bürgerinnen und Bürger).

A further interpretation of these findings may also be of institutional nature. While in the UK, the link to the constituents is locally grounded, in France, parliamentarians are representatives of the nation as a whole. As Norton (2012, 403) observes, "[f]undamental to the relationship between Parliament and citizen in the United Kingdom is a territorial base." One may theoretically distinguish between specific representation, which "entails defending and advancing the 
interests of a constituency and the individuals within it" (Norton 2012, 404), and general representation "as the defence of the causes of wider non-constituency interests in the country" (2012, 404). The corpus shows a very clear tendency to draw upon 'constituents' at the local level as a way to substantiate the MPs' claims - a finding that correlates with Norton's observation: "[i]n recent decades, the demands of specific representation have become greater" $(2012,405)$, thus explaining why "MPs have increasingly sought to make contact with constituents, collectively as well as individually" (2012, 410).

In France on the other hand, the MPs remain (more) representatives of the country: "the constitution determines a national mandate, despite the fact its electoral system (and representative practice) is focused on individual locally based districts" (Leston-Bandeira 2012, 271). Although it should be noted that "despite an abstract conception of representation, MPs are nevertheless very active at the local level” (Gabriel et al. 2018, 20), in comparison with Germany, "French MPs mention their role as representatives of the whole nation more often" $(2018,21)$. The French emphasis on the nation as a whole could be an explanatory factor for the divergences observed between French électeur (strictly negative) and English voter/constituent (strictly positive).

Germany finally presents a representative system in the middle position. Research has shown that MPs with direct mandates (direkt gewählt in German) tend to feel participate more in constituency work (Klingemann and Wessels 2001; Stratmann and Baur 2002), although the differences remain minor. This leads Coffé to observe that "[t]here is an ongoing debate in the literature over whether these two types of MP behave differently" $(2018,1)$. In order to test this hypothesis on the corpus, I have created a partition splitting up both voting systems. ${ }^{15}$ I have then looked for the lemmas Volk, Mensch, Bürger, and Leute and compared their specificity indicators. ${ }^{16}$ Although comparing the frequency of three lexemes arguably remains only a very partial indicator of the link to the constituency, it shows if MPs with a stronger local embeddedness tend to mention the people more often than MPs who have been elected through the party. The differences are not statistically significant for the lemmas Volk, Mensch, Bürger, and Leute. In order to

15 A partition (literally a 'division' of the corpus) is a command in the software TXM, based on the fact that the distinction between both possibilities in the German electoral system had been coded accordingly in a TEI-XML format.

16 The 'specificity indicator' (indice de spécificité) is a special command in TXM. Whenever a specificity indicator lies between [-2] and [+2], it is considered not to be statistically significant. The specificity indicator is particularly relevant when the different 'members' of a partition (here the variables 'direkt gewählt' vs. 'gewählt über Landesliste') are of unequal length (Lafon 1980, 128). 
make the comparison more robust, I have also searched for the personal pronoun man: here also, there is no difference between the two groups.

When using specific lexemes, Members of Parliament either stress the link with their constituency (my constituents, nos concitoyens, unsere Wähler) or, on the contrary, their opponents' failed attempts at establishing this link (vos électeurs, 'your constituents,' die Wähler, 'the voters'). In conclusion, linguistic factors - above all, semantic ones - determine the use of person-referring expressions more than institutional (i.e. between countries) and political differences (i.e. between parliamentary groups within each country).

\section{Making Parliamentary Debates Accessible: The Topos of 'Europe as a Machinery'}

In this section, I turn to a rhetoric and argumentative understanding of how giving the power back to the people is instantiated in parliamentary discourse on Europe. I will focus on the notion of topos, which I define as an argumentative commonplace used homogeneously between parliamentary groups and speakers and coming periodically, irrespective of the topic addressed. I examine the strong connection between the mention of the people and the topos of a crisis of representation in Europe. While political scientists have documented the idea of a crisis of democracy (Gabriel et al. 2018, 3; Michelsen and Walter 2013), discursive endeavors offer another perspective.

\subsection{The People as Subjects of Political Action: Making Europe Understandable 'for Everyone'}

The topos of 'Europe as a Machinery' and its consequence, 'Making Europe Understandable,' are paired with an interesting linguistic phenomenon. Although they are made the subjects of political actions, 'the people' are not semantic agents and syntactic subjects of sentences anymore. Rather, the person-referring expressions are embedded in prepositional groups, often beginning with the preposition for, which, in those utterances, "denotes a relation between an action and a beneficiary” (Tyler and Evans 2003, 154).

In the recurring topos of 'Europe as a Machinery,' the difficulty to understand what Europe is about is not phrased as 'people do not understand' or, reversely, as 'people should/will understand,' but as something that is (not) understandable for anyone: 
(14) Michael Stübgen (CDU) [majority]: In diesem Zusammenhang möchte ich kurz auf Island eingehen. Für jemanden, der das Thema nicht genau kennt, ist es nicht nachvollziehbar, worüber sich die SPD und die Grünen beschweren. (DE 2010.03.25)

Michael Stübgen (CDU) [majority]: In this context, I would like to briefly talk about Iceland. For someone who does not know the topic exactly, what the SPD and the Greens are complaining about is incomprehensible.

The indefinite pronoun 'someone' (jemand) introduces an indeterminate referent towards which the utterance is directed. Anticipating that citizens may not follow up on complex European issues, the speaker creates a class of referents defined by the fact that they are not familiar with the topic. Although this group consists mainly of citizens who are not specialists of European affairs, people are not named as such (e.g. 'people may not understand what we are saying, so let's make it clear for them'). The use of such an extended noun phrase can be interpreted as a face-saving act that avoids addressing the citizens ('you don't know') or mentioning them straightforwardly ('people don't know'). Citizens are integrated in the circle of all those who do not know much about Iceland, possibly inclusive of the speaker (who, as a member of an opposite parliamentary group, also finds what the Social Democrats and the Greens want incomprehensible).

Also consider (15):

(15) Valéry Giscard d'Estaing (UMP) [majority]: Cette Constitution, dont on parlait timidement il y a un an, et dont la nature est maintenant reconnue comme nécessaire par l'ensemble des membres de la Convention, cette Constitution lisible par tous, dans les lycées, dans les universités, dans les cours d'instruction civique, constituerait la première simplification du système européen. (FR 2002.12.03)

Valéry Giscard d'Estaing (UMP) [majority]: This Constitution, of which we timidly spoke a year ago, and whose necessary nature is now acknowledged by all members of the Convention, this Constitution, readable by all, in high schools, in universities, in civic education classes, would be the first simplification of the European system.

Similar to (14), Giscard d'Estaing pursues the goal of making the European constitution more readable for 'all,' and not for the citizens especially. MPs thus do not refer to 'the people' or 'the citizens' in such contexts, but rather to 'everyone' (tous, tout le monde, chacun, jedermann, jeder). The idea behind this inclusive stance is to avoid pointing at the people to stress their lack of knowledge: 
(16) Valéry Giscard d'Estaing (UMP) [majority]: Son rôle [le rôle du ministre des affaires étrangères de l'Europe unie], chacun le comprend, ne sera pas de décider tout seul la politique étrangère de l'Union et de se substituer à l'action diplomatique des Etats. (FR 2002.12.03)

Valéry Giscard d'Estaing (UMP) [majority]: Their role [that of the Ministry of European Affairs], everyone understands it, will not be to decide the foreign policy of the European Union all by himself or herself and to replace the diplomatic action of the [Member] States.

(17) Mr. Ian Taylor (Tories) [opposition]: The welcome attempt by Europe to play a greater defence role within NATO requires real leadership if the public are fully to understand that such great progress in politics will not come cheaply. (UK 1999.06.08)

(18) Mr. Tony Blair (Labour) [majority]: It is important that the people understand that in a couple of weeks' time euro notes and coins will be in circulation; 12 of the 15 European Union member states will be using that currency. (UK 2001.12.17)

Example (16) is different from examples (17) and (18). In the first case, 'everyone' is involved, while in the latter, 'the public' and 'the people' are mobilized. MPs paraphrase the lack of knowledge as something people should fight against ('everyone, MPs and citizens alike, should understand Europe better'). This is a way to present the illocutionary force at stake in a more inclusive manner. The phrasing 'everyone understands it' conceals the pressure exerted on the subject (i.e. 'you should understand,' 'you need to understand'). The structure if the public are fully to understand, however, underlines the need for the citizens, not the parliamentarians, to understand.

The mention of the people in such contexts enables a framing of European issues as something difficult which many do not (fully) understand. This is why in such cases, universal quantifiers such as 'everyone' or 'all' and indefinite pronouns such as 'someone' (examples 14, 15, 16) are more frequent than nouns such as 'people' or 'public' (examples 17 and 18). In the first case, the lack of knowledge is depicted as common ground, something that both Members of Parliament and citizens share. In the latter case, the reference to 'the people' becomes exclusive of the parliamentarians, who position themselves as educators. This common understanding of what doing 'being a Member of Parliament ${ }^{17}$ means is what constitutes parliamentarians as a community of practice.

17 This formulation derives from a conversation-analytic perspective that asks how we do 'being in a certain role,' i.e. how we perform certain activities in certain contexts. 


\subsection{Educating the People: Explaining Europe}

After considering how discourses on Europe are framed as not understandable with plenary debates aiming at making them easier to understand -, I now turn to the topos of educating the people by 'explaining' Europe. Interestingly, the use of the verb explain (erklären in German, expliquer in French) implies that once things are made clear, people may follow the politician's argumentation. The outcome, however, remains open: once the people know - which they assumingly do not yet -, they may still not be convinced.

The lexical representation activated by the verb 'explain' is thus different that the one opened by verbs such as 'convince' or 'persuade.' In comparison, the verbs überzeugen and convaincre ${ }^{18}$ ('convince,' 63 occurrences and 27 occurrences, respectively) are predominantly used in the first person singular (ich bin davon überzeugt, $j$ 'en suis convaincu/je suis persuadé19 'I am convinced of this') or, in the French corpus, plural (nous sommes convaincus, 'we are convinced'). The English verb persuade (20 occurrences) behaves slightly differently: it usually (in 17 cases out of 20) refers to external actors (partners, allies, countries) and to people or the British public in only three occurrences.

Extending Gledhill's $(2000,1)$ definition of phraseology as "the preferred way of saying things in a particular discourse", ${ }^{20}$ we can say that 'explain' is "the preferred way" of referring to the what politicians do when they talk to the people. The use of the verb 'explain' has two implications. First, the idea that is explained is framed as belonging to the realm of comprehension rather than argumentation. This rationalizes the speaker's stance, but also the hearer's final decision: once informed, the citizens can form a free opinion. Compared to convincing or persuading, which can trigger the idea of manipulation, explaining does not look like strategical maneuvering, as it is commonly associated with a presentation of facts. This first aspect is illustrated, in an ironic and adversative way, in examples (19) and (20), where the expected outcome is that people will disagree with the government's measures once they know what they mean. Second, the Members of Parliament act upon a superior epistemic status: they know more, and their task or moral duty is to inform their fellow citizens, as the deontic modal müssen ('must,' 'have to') shows in example (21). This is why despite all-encompassing noun phrases, referring to 'the people' usually excludes Members of Parliament:

18 There are only three occurrences of the lemma convince in the British corpus.

19 There is only one occurrence of the lemma persuader in the French corpus (je suis persuadé), and none of the verb überreden in the German corpus.

20 Gledhill was inspired by Kennedy's reflexions on "the role of corpus linguistics in identifying the preferred ways of putting things” (Kennedy 1992, 368). 
(19) Angus Robertson (Scottish National Party) [opposition]: Will he [the Prime Minister] explain to the people of Scotland, Wales and Northern Ireland why he thinks we are not good enough to attend in our own right, unlike the German Bundeslander [sic!]?

Mr. Tony Blair (Labour) [majority]: Relations and representation will be precisely the same as for the German Lander [sic!], so the hon. Gentleman is wrong. (UK 2001.12.17)

(20) Peter Hintze (CDU) [opposition]: Jetzt muss er [der Kanzler] den Bürgern erklären, wieso die Stimmgewichtung zwischen anderen Ländern fein austariert wird, während die Größe Deutschlands gegenüber kleineren aber keine Rolle spielt, und wie der Sand aus dem deutsch-französischen Getriebe wieder herauszubekommen ist. (DE 2001.01.19)

Peter Hintze (CDU) [opposition]: Now he [the chancellor] has to explain to the citizens why the weighting of votes between other countries is finely balanced, while the size of Germany plays no role compared to smaller ones, and how the sand can be removed from the Franco-German gearbox.

(21) Dr. Gregor Gysi (Die Linke) [opposition]: Hierzu würde ich gern erklären das muss man auch einmal den Leuten erklären -, was es mit einer Kreditausfallversicherung auf sich hat. (DE 2010.03.25)

Dr. Gregor Gysi (Die Linke) [opposition]: I would like to explain - one has to explain this to the people - what this has to do with a credit default insurance.

Example (21) is built around the opposition between the informal pronoun 'one' (man, which could also be rendered as generic you) the speaker belongs to and 'the people' to which things need to be 'explained' (erklären). Such a construction has two main consequences. First, Members of Parliament are implicitly extracted from the group of the people (Leute) since they are in the position to clarify the situation, not to be told what they should know. Although the speakers logically are people, 'the people' actually refers to the citizens, exclusive of the special group of citizens consisting of representatives.

These examples also proceed to a staging of the communicative act of explaining: instead of simply explaining (for instance, by just saying 'This has to do with a credit default insurance'), the speakers perform the communicative act of explaining. The parliamentarians metadiscursively label their utterance and name the communicative act they are performing. The orchestration of one's own words shapes in turn the image of the speaker. Here, it enables the speakers to take a step back and comment on their own actions. Through this shift in 
footing (being simultaneously doers and observers), a second category of targets next to the citizens is created: the peers. Colleagues indeed need (note the modal verb 'must,' müssen) to join the speaker in 'explaining' (also note the fuzzy group encapsulated in the indeterminate pronoun man).

In constructions where the discourse participants referred to are the ones for which or on which an action is performed, it becomes obvious that the 'people' designate only citizens, and not the Members of Parliament. By playing the role of educators or teachers, MPs paradoxically disconnect from the people. The teaching function of parliaments, which are "ought to alter [the society] for the better" and to "teach the nation what it does not know" (Bagehot 2001, 119), here finds its best expression.

In the Bundestag and the Assemblée nationale, all parliamentarians use the topos of 'Europe as a Machinery' by accusing their opponents of not explaining their policies clearly enough:

(22) Alexander Ulrich (DIE LINKE) [opposition]: Herr Schäuble, Sie müssen der schwäbischen Hausfrau einmal erklären,

Sabine Weiss (CSU) [majority]: Lassen Sie die arme schwäbische Hausfrau in Ruhe!

Alexander Ulrich (DIE LINKE) [opposition]: warum man angesichts der derzeitigen Niedrigzinspolitik dringende Investitionen nicht jetzt tätigt, sondern wartet, bis die Zinssätze wieder steigen. (DE 2014.10.16)

Alexander Ulrich (DIE LINKE) [opposition]: Mr. Schäuble, you have to explain to the Swabian housewife,

Sabine Weiss (CSU) [majority]: Leave the poor Swabian housewife alone! Alexander Ulrich (DIE LINKE) [opposition]: why, in view of the current low interest rate policy, urgent investments are not being made now, but are waiting until interest rates rise again.

The leitmotif of the 'Swabian housewife' (schwäbische Hausfrau) was first used by Angela Merkel, serving as Chancellor of Germany since 2005, during the CDU political convention in Stuttgart in December 2008 (see Rinke 2016). It has become the image of an ordinary citizen expressing common sense in lieu of the trained politician (see Truan 2016, para. 54 for other examples, and notably 'an old inhabitant of Poitou-Charente, an often sympathetic figure, always filled with common sense' in the French corpus). ${ }^{21}$ Here a member of the opposition alludes

21 Interestingly, both these vivid figures do not correspond to the unmarked middle-aged white male. Whether this is purely incidental or may be a more general pattern remains to be investigated. 
to this catch phrase in an ironic way. Although the number of occurrences of the lemma erklären ('explain') remains small (110 occurrences), the specificity indicator does not point to any specific use by a parliamentary group. Similarly, the French verb expliquer (25 occurrences) cannot be tied to any parliamentary group.

Recurring to the need for explanations is nevertheless contested, as the following example from the French corpus shows:

(23) Jean-François Copé (UMP) [majority]: Je me suis interrogé également sur les raisons qui avaient pu conduire tant de Français à rejeter cette Constitution. On nous a dit qu'elle était mal expliquée, qu'elle était ambiguë, qu'elle était déconnectée des attentes de beaucoup de nos concitoyens. Peutêtre. Mais le message essentiel qu'ont voulu nous faire passer nombre de Français, c'est qu'ils ne croyaient plus en la politique. "À quoi bon? ", nous disaient-ils, "On ne vous croit plus ! » (FR 2007.12.11)

Jean-François Copé (UMP) [majority]: I also wondered about the reasons that could have led so many French people to reject this Constitution. We have been told [literally: One told us] that it was ill-explained, that it was ambiguous, that it was disconnected from the expectations of many of our fellow citizens. Perhaps. But the essential message that a number of French people wanted to communicate is that they no longer believed in politics. "What's the point?," they were telling us, "We do not believe you anymore!.”

Example (23) combines several discursive moves typical for the corpus of parliamentary debates under investigation: mapping out people's expectations ('the expectations of many of our fellow citizens'), denoting the same referents in various ways ('French people,' fellow citizens'), enacting the people's voice through reported speech, or, as Tannen (2007) phrases it, "constructed dialogue" ("What's the point?," they were telling us, "We do not believe you anymore!," see Truan 2016). This excerpt is also one of the few disregarding the need for explanation. According to Jean-François Copé, arguing that the French No in the referendum on the Constitutional Treaty in 2005 was 'ill-explained' falls short: the adverb 'perhaps' condenses his skepticism.

Interestingly, the necessity to explain Europe is not made (as) relevant in the British parliament. The verb explain (47 occurrences) is used in two structures. The first one pertains to the speech act 'demanding an explanation to the Prime Minister': will/can he explain/he has to explain (sometimes phrased as a reproach: The Prime Minister did not explain). Conversely, the opposite pattern, Let me explain/I have explained, introduces the desired information. Despite the small number of occurrences, it is interesting to note that the beneficiaries 
of such explanations are rather the House (2 occurrences) or the hon.[orable] Members (1 occurrence) than the people of Scotland, Wales and Northern Ireland (1 occurrence), which tends to show that the - expressed - targets of parliamentary talk are peers. Arguably, such findings must be taken cautiously; the use of one lemma cannot be held to reveal broader discursive practices. The non-mention of the citizens can, however, be interpreted in light of the British view on European integration. Since the debates on European Councils remain technical (Truan 2016, para. 16), it can be hypothesized that they are not aimed at teaching (or convincing) outside the House of Commons. Furthermore, all the plenary debates in the British parliament take place after the European Council (ex post), so that Members of Parliament know their discussions will not influence the outcome of the European Council.

More generally, the teaching enterprise in the corpus corresponds to the opinion of the mainstream parliamentary groups according to which, if 'the people' do not like Europe, it is (only/simply) because they do not comprehend it. Example (24) illustrates the tension between 'pedagogy' and 'demagogy':

(24) Stéphane Demilly (Nouveau Centre) [majority]: À ce titre, nous ne pouvons qu'encourager les gouvernements européens à faire la pédagogie de l'Europe auprès de leurs opinions publiques et à ne pas laisser le champ libre aux démagogues de tout poil...

Roland Muzeau (Gauche Démocrate et Républicaine) [opposition]: C'est vous qui fabriquez les démagogues!

Stéphane Demilly (Nouveau Centre) [majority]: ...qui veulent faire de l'Europe le bouc émissaire de tous les problèmes. (FR 2011.12.06)

Stéphane Demilly (Nouveau Centre) [majority]: As such, we can only encourage European governments to educate their public opinion about Europe and not to leave the field open to demagogues of any kind...

Roland Muzeau (Gauche Démocrate et Républicaine) [opposition]: You're the one who is creating demagogues!

Stéphane Demilly (Nouveau Centre) [majority]: ....who want to make Europe the scapegoat for all problems.

The argument from the Nouveau Centre (center-right parliamentary group) is that 'demagogues' (understand: parties against a further European integration who voted against the Constitutional Treaty in 2005, including members of the Socialist Party, the Far Left, and right-wing parties such as the National Front) blame Europe for all their problems instead of 'educat[ing] their public opinion.' Drawing a line between demagoguery and populism remains a tricky enterprise (Charaudeau 2011, 101), and this paper does not claim to resolve the tension. What 
is visible in this excerpt, however, is how 'being a demagogue' - a word often used in lieu of 'populist' - functions as a process of othering: refusing to educate the people is demagoguery. At the same time, the ideological goal underlying proEuropean parties is clear: people should be taught to want (more) Europe. The underlying assumption is that people do not (really) know what they want but that politicians do: people would want (more) Europe if they really understood. This may be what is captured in Muzeau's call in-between 22 'You're the one who is creating demagogues!,' in which he passes the buck to his colleague.

The analyses from this section have shown that the topos of 'Europe as a Machinery' unfolds in two main patterns. The difficulty in understanding the ins and outs of the European Union, which maximizing quantifiers ('everyone,' 'anyone') render as a shared experience, makes people the beneficiaries of political action (preposition for). Based on this observation, Members of Parliament metadiscursively comment on the necessity, in their view, to educate the people on Europe. This line of argumentation does not unfold without contradiction. On the one hand, the necessity to explain Europe to people implies that Members of Parliament know better, and are in the position to teach their fellow citizens. On the other hand, parliamentarians rely on the people, who embody common sense, as the mention of the 'Swabian housewife' or the 'old inhabitant of Poitou-Charente' shows. While accounting for the complexity of European affairs seems to drive all parliamentarians, it is not without its problems. When does the teaching enterprise become an elitist move, accenting the gap between those are knowledgeable and those who are not? When does it become an argument for not wanting a people's vote, claiming that uninformed people cannot make their own decisions?

\section{Conclusion}

The articulation between populism and language remains heavily discussed. Instead of looking for features of a populist style, this study of British, German, and French parliamentary debates on Europe has addressed the reverse question: how do Members of Parliament account for the necessity to mention the people without highlighting their position of representatives? More generally speaking, how are 'the people' represented in political discourse?

22 Shorter, unauthorized turns by speakers other than the one currently holding the floor are common in parliamentary settings. While they are usually labelled as 'interruptions,' I suggest the term 'calls in-between' as a possible translation of the German term Zwischenruf, which, in my view, better accounts for this type of interaction. 
This article has shown that referring to the people is a common feature of parliamentary talk for all speakers and all parliamentary groups. Giving the power back to the people in parliamentary discourse on Europe is characterized by a twofold dynamic. First, the people are the backing parliamentarians need in order to present their argument as emanating from the people - the volonte générale. While a variety of expressions can refer to the people, the Members of Parliament are not included in 'the people' they talk about. By giving the people a voice (sometimes in the literal sense, through constructed dialogue), Members of Parliament talk on behalf of the people. They also argue that they speak for them, and put forth their views by claiming that these are the people's. Although this feature is commonly viewed as a sign of populism, the fact that all parliamentarians do it in similar ways and proportions calls this claim into question.

Second, the people are those for which plenary debates take place, as parliamentary discourse serves educational goals. The teaching mission that many parliamentarians endorse is directed towards the people. This means that, per extension, parliamentarians also talk to the people. Yet parliamentarians do not simply explain European affairs, they perform the act of explaining it. In doing so, Members of Parliament constitute themselves as a community of practice by stressing shared knowledge about technical issues and their teaching vocation as a common objective.

The contradiction between speaking on behalf of the people, which means instead of them, and empowering the people by giving them the resources to understand, is not resolved in the corpus. This inconsistency may be explained by the fact that Members of Parliament, despite their efforts to include their constituents in politics, still see citizens as people who need to be informed. To what extent this double bind may precisely be a feature of populist discourse may open avenues for further research. What this study has shown, however, is that the mere mention of 'the people,' even in homogenizing terms, is not what constitutes populism.

\section{Corpora}

Truan, Naomi (2016a). Parliamentary Debates on Europe at the Assemblée nationale (20022012) [Corpus]. ORTOLANG (Open Resources and TOols for LANGuage). hdl.handle. net/11403/fr-parl.

Truan, Naomi (2016b). Parliamentary Debates on Europe at the Deutscher Bundestag (1998-2015) [Corpus]. ORTOLANG (Open Resources and TOols for LANGuage). hdl.handle. net/11403/de-parl.

Truan, Naomi. (2016c). Parliamentary Debates on Europe at the House of Commons (19982015) [Corpus]. ORTOLANG (Open Resources and TOols for LANGuage). hdl.handle. net/11403/uk-parl. 


\section{Works Cited}

Bagehot, Walter (2001 [1867]). The English Constitution. Cambridge: Cambridge University Press.

Baker, Paul, Andrew Hardie and Tony McEnery (2006). A Glossary of Corpus Linguistics. Edinburgh: Edinburgh University Press.

Boughanmi, Jihene (2016). Sur les collectifs humains. SHS Web of Conferences 27, 12004.

Cappeau, Paul and Catherine Schnedecker (2014). Gens, personne(s), individu(s): trois saisies de l'humain. Franck Neveu, Peter Blumenthal, Linda Hriba, Annette Gerstenberg and Judith Meinschäfer, eds. 4ème Congrès Mondial de Linguistique Française, vol. 8, Berlin, 3027-3040.

Charaudeau, Patrick (2011). "Réflexions pour l'analyse du discours populiste." Mots. Les langages du politique 97, 101-116.

Coffé, Hilde (2018). “MPs' Representational Focus in MMP Systems. A Comparison Between Germany and New Zealand." Representation 54.4, 367-389.

Ekström, Mats, Marianna Patrona and Joanna Thornborrow (2018). "Right-Wing Populism and the Dynamics of Style: A Discourse-Analytic Perspective on Mediated Political Performances." Palgrave Communications 4.1, 83.

Francis, Winthrop Nelson and Henry Kučera (1982). Frequency Analysis of English Usage: Lexicon and Grammar. Boston: Houghton Mifflin.

Gabriel, Oscar W., Éric Kerrouche, Suzanne S. Schüttemeyer and Sven T. Siefken (2018). "Introduction: Political Representation in France and Germany." Oscar W. Gabriel, Éric Kerrouche and Suzanne S. Schüttemeyer, eds. Political Representation in France and Germany. Attitudes and Activities of Citizens and MPs. Cham: Palgrave Macmillan, 1-57.

Gledhill, Christopher J. (2000). Collocations in Science Writing. Tübingen: Gunter Narr. Heiden, Serge (2010). The TXM Platform: Building Open-Source Textual Analysis Software Compatible with the TEI Encoding Scheme. 389-398. Institute for Digital Enhancement of Cognitive Development, Waseda University. Online: https://halshs.archives-ouvertes.fr/ halshs-00549764/document (March 16, 2017).

Hermet, Guy (2001). Les populismes dans le monde. Une histoire sociologique, XIXe-XXe siècle. Paris: Fayard.

Higgins, Michael (2013). “Governmentality, Populism and Empowerment: David Cameron's Rhetoric of the Big Society." Richard Scullion, Roman Gerodimos, Daniel Jackson and Darren Lilleker, eds. The Media, Political Participation and Empowerment. Abingdon: Routledge, 58-70.

Hoffmann, Lutz (1991). "Das ,Volk‘. Zur ideologischen Struktur eines unvermeidbaren Begriffs." Zeitschrift für Soziologie 20.3, 191-208.

Hubé, Nicolas and Naomi Truan (2016). “France: The Reluctance to Use the Word ‘Populism’ as a Concept.” Toril Aalberg, Frank Esser, Carsten Reinemann, Jesper Stromback and Claes de Vreese, eds. Populist Political Communication in Europe. A Cross-National Analysis of European Countries. New York: Routledge, 181-194.

Kennedy, Graeme (1992). "Preferred Ways of Putting Things with Implications for Language Teaching." Jan Svartvik, ed. Directions in Corpus Linguistics (Trends in Linguistics 65). Berlin and New York: Mouton de Gruyter, 335-373.

Klingemann, Hans-Dieter and Bernhard Wessels (2001). "The Political Consequences of Germany's Mixed-Member System: Personalization at the Grass Roots?” Matthew Soberg 
Shugart and Martin P. Wattenberg, eds. Mixed-Member Electoral Systems. The Best of Both Worlds? (Comparative European Politics). Oxford: Oxford University Press, 279-296.

Lafon, Pierre (1980). "Sur la variabilité de la fréquence des formes dans un corpus." Mots. Les langages du politique 1.1, 127-165.

Lecolle, Michelle (2013). "Noms collectifs humains : un point de vue de sémantique lexicale sur l'identité dans le rapport individu/groupe." ¿Interrogations? Identité fictive et fictionnalisation de l'identité (II)(46). Online: http://www.revue-interrogations.org/ NOMS-COLLECTIFS-HUMAINS-UN-POINT (October 25, 2016).

Leston-Bandeira, Cristina (2012). "Parliaments' Endless Pursuit of Trust: Re-Focusing on Symbolic Representation.” The Journal of Legislative Studies 18.3-4, 514-526.

Mayaffre, Damon and Ronny Scholz (2017). “Constructing 'the French people' - On Sarkozy's Populism." Journal of Language and Politics 16.5, 683-705.

Michelsen, Danny and Franz Walter (2013). Unpolitische Demokratie: Zur Krise der Repräsentation. Berlin: Suhrkamp.

Moffitt, Benjamin (2016). The Global Rise of Populism: Performance, Political Style, and Representation. Stanford: Stanford University Press.

Norton, Philip (2012). "Parliament and Citizens in the United Kingdom." The Journal of Legislative Studies 18.3-4, 403-418.

Pitkin, Hanna F. (1967). The Concept of Representation. Berkeley and Los Angeles and London: University of California Press.

Rabatel, Alain (2016). "De la difficulté de catégoriser le peuple (des invisibles) en échappant aux jugements de valeur." Exercices de rhétorique 7. Online: https:// rhetorique.revues. org/457 (June 20, 2016).

Retterath, Jörn (2016). ,Was ist das Volk?؛ Volks- und Gemeinschaftskonzepte der politischen Mitte in Deutschland 1917-1924. Berlin and Boston: Walter de Gruyter.

Rinke, Andreas (2016). Das Merkel-Lexikon: Die Kanzlerin von A-Z. Springe: Klampen.

Schnedecker, Catherine and Wiltrud Mihatsch, eds. (2018). Les noms d'humains - théorie, méthodologie, classification. Nouvelles approches en sémantique lexicale. Berlin and Boston: Mouton de Gruyter.

Steeg, Marianne van de (2010). "The European Council's Evolving Political Accountability." Mark Bovens, Deirdre Curtin and Hart Paul 't, eds. The Real World of EU Accountability. What Deficit?. Oxford: Oxford University Press, 117-149.

Stratmann, Thomas and Martin Baur (2002). "Plurality Rule, Proportional Representation, and the German Bundestag: How Incentives to Pork-Barrel Differ across Electoral Systems." American Journal of Political Science 46.3, 506-514.

Taguieff, Pierre-André (2002). L'illusion populiste. De l'archaïque au médiatique. Paris: Berg International.

Tannen, Deborah (2007). Talking Voices. Repetition, Dialogue and Imagery in Conversational Discourse. 2nd ed. Cambridge: Cambridge University Press.

Truan, Naomi (2016). “"Les citations doivent être exactes!». Pratiques polémiques de la citation au parlement." Travaux interdisciplinaires sur la parole et le langage 32. Online: https://tipa.revues.org/1689.

Truan, Naomi (2019a). “The Discursive Construction of the People in European Political Discourse. Semantics and Pragmatics of a Contested Concept in German, French, and British Parliamentary Debates." Jan Zienkowski and Ruth Breeze, eds. Imagining the Peoples of Europe: Populist Discourses Across the Political Spectrum (Discourse Approaches to Politics Society and Culture 83). Amsterdam and Philadelphia: John Benjamins, 201-228. 
Truan, Naomi (2019b). “Möglichkeiten und Herausforderungen einer pragmatisch orientierten kontrastiven Diskursanalyse. Ein Vorschlag am Beispiel deutscher, französischer und britischer Parlamentsdebatten.” Diskurse - digital 1.3, 29-50. Online: https://majournals. bib.uni-mannheim.de/diskurse-digital/article/view/104. (August 20, 2019).

Tyler, Andrea and Vyvyan Evans (2003). The Semantics of English Prepositions: Spatial Scenes, Embodied Meaning, and Cognition. Cambridge: Cambridge University Press.

Vorländer, Hans, Maik Herold and Steven Schäller (2018). PEGIDA and New Right-Wing Populism in Germany. Cham: Springer.

Wodak, Ruth (2015). The Politics of Fear: What Right-Wing Populist Discourses Mean. Los Angeles, London, New Dehli, Singapore, Washington, DC: Sage. 